\title{
Homing and site fidelity in the greasy grouper Epinephelus tauvina (Serranidae) within a marine protected area in coastal Kenya
}

\author{
Boaz Kaunda-Arara ${ }^{1, *}$, George A. Rose $^{2}$ \\ ${ }^{1}$ Department of Fisheries, Moi University, PO Box 1125, Eldoret, Kenya \\ ${ }^{2}$ Marine Institute of Memorial University, PO Box 4920, St. John's, Newfoundland, A1C 5R3, Canada
}

\begin{abstract}
Homing ability and site-fidelity in the greasy grouper Epinephelus tauvina (Serranidae) were studied at Malindi Marine Park $\left(6.3 \mathrm{~km}^{2}\right)$, coastal Kenya, from January to April 2002 using acoustic telemetry. Displacement experiments involving 12 groupers (mean size $57.9 \mathrm{~cm}$ ) from multiple capture sites resulted in a $67 \%$ homing success. Upon release at displacement sites $(0.5$ to $2.6 \mathrm{~km}$ from the point of capture), most initial movements were small-scale and non-directional. Neither the tidal range nor time of day influenced the magnitude of these daily movements. Returns to the capture sites were sudden, occurring predominantly ( $88 \%)$ on spring tide dates. Fish displaced at the spring tide returned to capture sites faster $(8.6 \mathrm{~d})$ than those displaced at the neap tide $(14.3 \mathrm{~d})$. Time taken to return to capture sites ranged from 4 to $19 \mathrm{~d}$ (mean $9.6 \mathrm{~d}$ ) and was not correlated with distance of displacement. However, time taken for the fish to home was negatively correlated with tidal range at displacement. Home ranges established after homing $\left(0.07\right.$ to $\left.0.73 \mathrm{~km}^{2}\right)$ were stable and negatively correlated with fish size, suggesting an ontogenetic shift in home range development.
\end{abstract}

KEY WORDS: Marine reserves $\cdot$ Coral reefs $\cdot$ Spring tides $\cdot$ Home range

\section{INTRODUCTION}

Homing may be defined as the return of an animal to a place formerly occupied rather than to equally habitable places (Gerking 1959), and has been documented in many species (Papi 1992). Among the teleost fishes, homing is best documented in the salmonids (Ditman \& Quinn 1996) and has also been reported in coastal marine fishes (Green 1971, Robichaud \& Rose 2001). The mechanisms by which fishes home are not well known. Laboratory studies have documented the ability of fishes to detect visual and olfactory cues (Ditman \& Quinn 1996) and other stimuli such as electric and magnetic fields (Quinn \& Ditman 1992). Familiarity with the physical environment (currents, tides and bathymetry) and learning have also been postulated as mechanisms of homing in fishes (Helfman et al. 1982, Rose 1993).

Although many coral reef fishes show site-fidelity (Sale 1991), the ability to home has been demonstrated in only a few species (e.g. Warner 1995, Marnane 2000). Evidence for homing in coral reef fishes has mostly been limited to incidental observations of fishes returning to feeding, shelter or spawning sites (Switzer 1993). Constraints imposed by the methods of capture and visual re-sighting of tagged fishes have largely precluded studies of homing of larger fishes with larger home ranges. However, recent developments in ultrasonic telemetry (e.g. Holland et al. 1993, Zeller 1997) relieve this limitation. The groupers (family Serranidae) are relatively large, long-lived reef fishes of commercial value with worldwide distribution in tropical oceans (Russ 1991). Some species migrate to distinct reef sites, where they form spawning aggregations (Beets \& Friedlander 1998, Sala et al. 2001). Their sedentary habits, large size, low reproductive rates and the existence of spawning aggregations in some species have facilitated over-exploitation of grouper populations worldwide (Morris et al. 2000, Sala et al. 
2001). Within marine reserves, homing and site-fidelity may enhance the likelihood of sustaining locally reproducing populations that could provide sources of dispersing larval recruits for adjacent areas (Sluka et al. 1996). However, there have been few studies of the abilities of groupers to home to specific sites or of the extent of their home ranges. In this study, we used ultrasonic telemetry to assess the homing behavior of greasy groupers Epinephelus tauvina of various sizes (large groupers of this species are up to $75 \mathrm{~cm}$ in length and $>5 \mathrm{~kg}$ in weight). We also examined the hypotheses that home ranges are size-dependent and that homing abilities relate to fish size and to tidal conditions. dominal wall slightly above the central line posterior to the ventral fins. An ultrasonic transmitter tag $(3.2 \times$ $0.85 \mathrm{~cm}$, Lotek) was inserted into the abdominal cavity through the incision, which was then closed with gut sutures. The surgery and tag implantation took approximately 2 to $3 \mathrm{~min}$. Each tag transmitted a distinct electronic numeric identification code on a frequency of $77 \mathrm{kHz}$ every $5 \mathrm{~s}$. Transmitters had an estimated longevity (battery-life) of 6 mo. Following surgery, total length was measured (nearest $\mathrm{mm}$ ) and an external tag (Floy FD-94) was inserted into the dorsal musculature. The fish was then transferred to a 1001 basin containing fresh seawater and revived through repeated mech-

\section{MATERIALS AND METHODS}

Study site. Kenya has 4 national marine parks along its $650 \mathrm{~km}$ long coastline that provide coral reef communities with total protection from extractive exploitation. The present research was done at Malindi National Marine Park (6.3 km²) (Fig. 1), created in 1968. The park contains part of a continuous near-shore fringing reef and several patch reefs. The fringing reef is an erosional fossil (with little live coral growth) located about $200 \mathrm{~m}$ from the high-water mark, spanning the park, and extending several kilometers outside the park boundaries. The North Reef, a flat of semifossil platform reef that is exposed at low tides, is the largest $(2 \times 1 \mathrm{~km})$ patch reef within the park, located about $1 \mathrm{~km}$ from shore. The park also includes a submerged patch reef (Tewa Reef) south of North Reef (Fig. 1).

Fish tagging. Groupers were captured at 3 sites (Fig. 1) within the park using traditional 'Dema' traps commonly used by fishermen in coastal Kenya. Individual fish were selected for tagging based on criteria of minimum size (30 cm total length) and good body condition. Groupers to be tagged were placed in a 501 basin containing about 101 of seawater. Small quantities of anaesthesia (MS222, Argent) were then incrementally added to the seawater until the fish lost equilibrium and became calm. No attempt was made to standardize the concentration of the anasthetic solution, as the effective dosage varied between individuals and with ambient temperature $\left(25\right.$ to $\left.35^{\circ} \mathrm{C}\right)$. In order to minimize stress, surgery was then conducted with the fish held ventro-dorsally with the opercular slit immersed in seawater. A longitudinal incision $(\sim 1 \mathrm{~cm}$ and just large enough to insert the tag) was made in the ab-
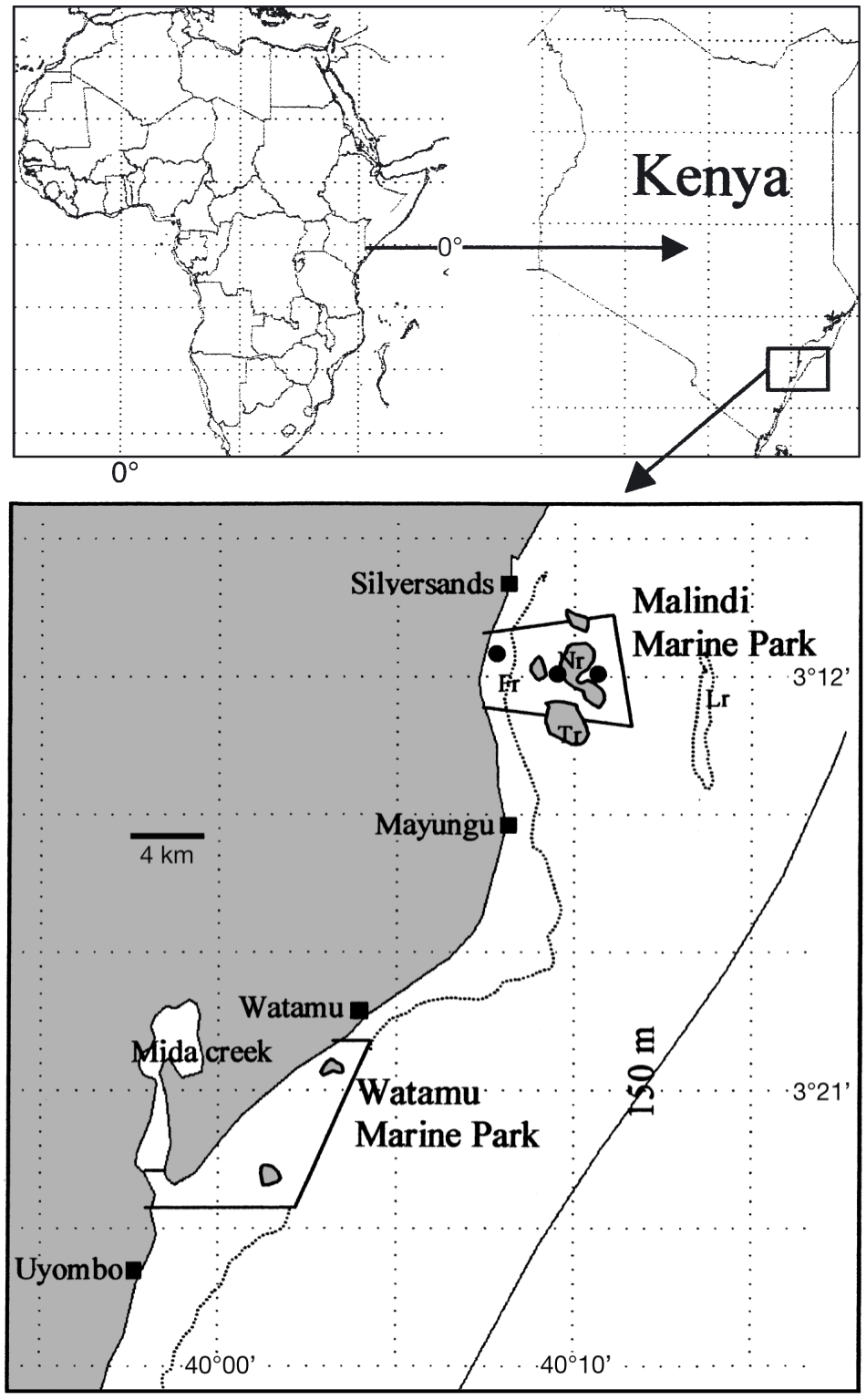

Fig. 1. Study site showing capture points $(\bullet)$ of greasy groupers Epinephelus tauvina at Malindi Marine Park and reefs and adjacent fished sites in coastal Kenya. Nr: North reef; Fr: Fringing reef; Tr: Tewa reef; Lr: Leopard reef 
anical aeration of the water. Fish normally revived and became active within 5 to $15 \mathrm{~min}$. Visual observations on 2 recaptured fish indicated that their incisions healed completely within 1 to 2 wk.

Displacement experiments and tracking. We tagged 14 groupers comprising 12 translocated fish and 2 controls released at the capture site (Table 1). The fish were translocated under anaesthesia to release sites ( 0.5 to $2.6 \mathrm{~km}$ away) by boat and released only after apparent full recovery. Release sites were randomly selected, but had a gross topographic complexity similar to the capture sites. The initial movements of most fish were usually monitored underwater soon after release by a diver. Upon release, most fish visited different coral heads before settling down within a reef crevice. Tracking began immediately after release from a $5.5 \mathrm{~m}$ open boat with a manually operated portable receiver (Lotek, SRX_400) and an omnidirectional hydrophone (Lotek). As most fish moved infrequently during tracking, the tracking routine was restricted to a daily single location of each tagged fish.

Release sites were visited daily following tagging. During a tracking session, the SRX receiver was initially set at the highest possible gain that did not overload the detection circuits. When a signal was detected, the boat was maneuvered in the apparent direction of the signal whilst the gain was gradually reduced to zero. Most fish were located to within a few meters of the boat, and their position was logged using a hand-held Garmin GPS receiver. Whenever a fish was not detected at the release site, the capture site was visited to check for the possibility of a return. If the fish was not at the capture site, the boat drifted along parallel transects over the site of last location, with the number of drifts and drift area being increased whenever the fish was not located. Daily tracking periods averaged $4 \mathrm{~h}$ and were distributed haphazardly over the $12 \mathrm{~h}$ daylight period. The fish was considered to have homed on the date of first detection at the capture site. Most fish were detected at capture sites within $1 \mathrm{~d}$ of their last location at the release site.

Data analysis. The minimum polygon area (Winter \& Ross 1982), which represents a non-statistical measure of dispersion over the total area used by an individual, was used as a measure of home range size. All position fixes for a given fish were plotted using Mapinfo 4.1 software (Mapinfo) onto a map of the park, and the outermost positions were connected by straight lines to form a polygon. Positions that were considered anomalous GPS records (outside the possible spatial range) resulting from unknown error sources were excluded from the polygon. The aspect ratio (AR), a ratio of the largest diagonal to the largest width of the home range area, was used to describe the shape of the home range. Oblong and circular shapes have AR values greater and less than 2, respectively (Winter 1977). Observation-area curves (number of observations vs total area covered, Odum \& Kuenzler 1955) were used to examine the stability of the home ranges demarcated for each fish. Linearity ratios (LR) (Danielson \& Swihart 1987) were used to test for randomness of movements of individuals at sites of release. LR, the ratio of the distance between an individual's first and last positions and the total distance moved by an individual during the complete tracking period, is a measure of the directedness of movements, with values tending to zero if movements are random, and to unity if movements are unidirectional.

Table 1. Epinephelus tauvina. Summary statistics of tagging and return (homing) conditions and dates (d/mo) for greasy groupers tagged and released at multiple sites within Malindi National Marine Park, coastal Kenya, during January to April 2002 $(\%$ fixes $=$ days located/days tracked $\times 100)$

\begin{tabular}{|c|c|c|c|c|c|c|c|c|c|c|c|}
\hline $\begin{array}{l}\text { Fish ID } \\
\text { code }\end{array}$ & $\begin{array}{l}\text { Total } \\
\text { length } \\
(\mathrm{cm})\end{array}$ & $\begin{array}{l}\text { Distance } \\
\text { released } \\
\quad(\mathrm{km})\end{array}$ & \multicolumn{2}{|c|}{$\begin{array}{l}\text { Date of } \\
\text { release return }\end{array}$} & $\begin{array}{l}\text { Days } \\
\text { taken to } \\
\text { return }\end{array}$ & $\begin{array}{l}\text { Tid } \\
\text { release }\end{array}$ & at return & \multicolumn{2}{|c|}{$\begin{array}{l}\text { No. of days } \\
\text { tracked located }\end{array}$} & $\begin{array}{l}\% \\
\text { fixes }\end{array}$ & $\begin{array}{c}\text { Max. days } \\
\text { between } \\
\text { locations }\end{array}$ \\
\hline \multicolumn{12}{|c|}{ Experimental } \\
\hline 37 & 49.0 & 1.5 & $26 / 2$ & $4 / 3$ & 6 & Spring & Spring & 53 & 38 & 71.7 & 102 \\
\hline 36 & 65.0 & 1.2 & $9 / 1$ & $18 / 1$ & 9 & Neap & Spring & 53 & 17 & 32.1 & 85 \\
\hline 128 & 66.0 & 1.6 & $5 / 3$ & $19 / 3$ & 14 & Spring & Spring & 23 & 18 & 78.3 & 40 \\
\hline 155 & 68.0 & 0.5 & $24 / 2$ & $11 / 3$ & 15 & Neap & Spring & 32 & 24 & 75.0 & 58 \\
\hline 84 & 57.5 & 0.5 & $27 / 3$ & $10 / 4$ & 13 & Spring & Spring & 18 & 16 & 88.9 & 34 \\
\hline 140 & 64.0 & 1.0 & $28 / 2$ & $6 / 3$ & 6 & Spring & Neap & 28 & 19 & 67.9 & 45 \\
\hline 122 & 55.3 & 1.2 & $12 / 4$ & $16 / 4$ & 4 & Spring & Spring & 5 & 5 & 100 & 5 \\
\hline 116 & 64.0 & 2.6 & $24 / 2$ & $16 / 3$ & 19 & Neap & Spring & 24 & 16 & 66.7 & 38 \\
\hline 152 & 34.0 & 1.5 & $24 / 2$ & - & - & Neap & - & 34 & 26 & 76.5 & 58 \\
\hline $56^{a}$ & 54.0 & 1.0 & $2 / 1$ & - & - & Spring & - & 53 & 1 & 1.9 & - \\
\hline $83^{a}$ & 60.0 & 1.2 & $23 / 2$ & - & - & Neap & - & 32 & 7 & 21.9 & 9 \\
\hline $133^{\mathrm{a}}$ & 54.5 & 2.6 & $24 / 2$ & - & - & Neap & - & 14 & 1 & 7.1 & - \\
\hline \multicolumn{12}{|l|}{ Control } \\
\hline & 65.3 & - & - & - & - & - & - & 63 & 17 & 27.0 & 94 \\
\hline $160^{\mathrm{a}}$ & 54 & - & - & - & - & - & - & 53 & 31 & 58.5 & 105 \\
\hline
\end{tabular}




\section{RESULTS}

Of the 12 groupers displaced within the park, 8 (67\%) homed to their capture sites within 4 to $19 \mathrm{~d}$ (mean $9.6 \pm 5.3$ d) (Table 1, Fig. 2). The other 4 fish did not return to the sites of capture. Of these 4 nonhomers, the fish coded as 133 was captured by fishermen outside the park $10 \mathrm{~d}$ after translocation.
Codes 56 and 83 could not be relocated after 1 and $7 \mathrm{~d}$, respectively, while Code 152 stayed near the site of release throughout the study. Among the fish that homed, Code 155 was not detected at the release site for $7 \mathrm{~d}$ prior to being detected at the capture site, while the other 7 fish were detected at capture sites within $1 \mathrm{~d}$ of their last location at the release site.
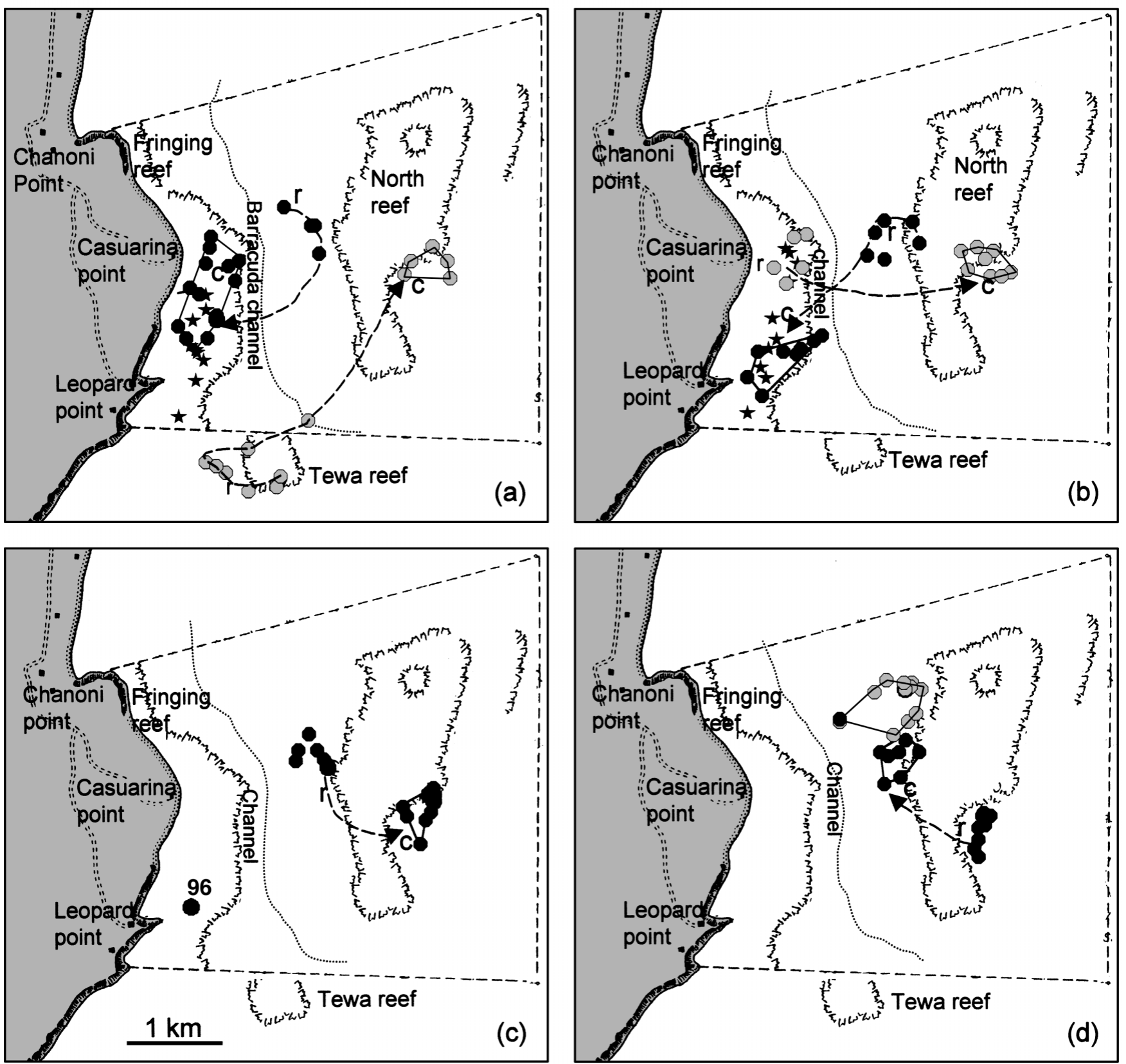

Fig. 2. Epinephelus tauvina. Homing activity of individuals captured and released at multiple sites (0 to $2.6 \mathrm{~km}$ ) within Malindi Marine Park, Kenya. Dashed lines show likely direction of movements from release (r) to capture (c) sites during homing; stars show positions of coral heads on fringing reef; polygons demarcate home range upon return to capture site. (a) Fish coded $37(\bullet)$ and $116(\bullet)$; (b) Codes $36(\bullet)$ and $128(\bullet)$; (c) Codes 96, $155(\bullet)$; (d) Codes $84(\bullet)$ and $152(\bullet)$ 


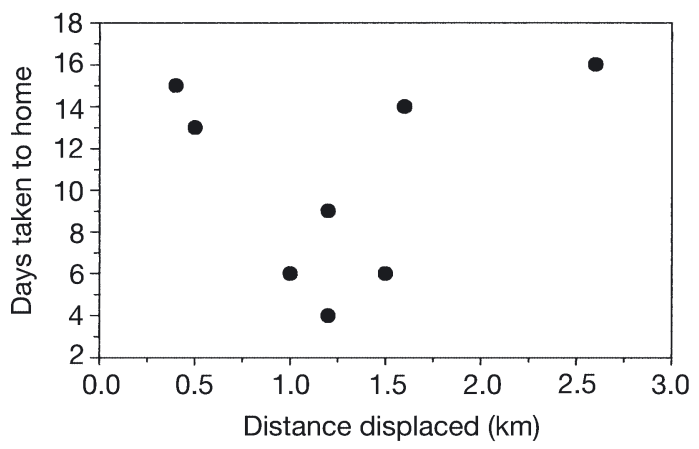

Fig. 3. Epinephelus tauvina. Relationship between days taken to return to capture sites and distance of displacement within Malindi Marine Park, coastal Kenya $\left(\mathrm{r}^{2}=0.185, \mathrm{p}>0.05\right)$

Of the homing fish, 7 (88\%) returned on spring tide (full-moon lunar phase) (Table 1). Fish that were displaced on dates that coincided with spring tides returned to the capture site more quickly (mean $8.6 \pm$ $4.6 \mathrm{~d}$ ), than did fish displaced on neap tides (half-moon lunar phase) (mean $14.3 \pm 5.0 \mathrm{~d}$ ) (Mann-Whitney $U$-test $=17, \mathrm{df}=4,2, \mathrm{p}<0.05)$. The number of days taken to home was inversely related to tidal range at displacement (Spearman rank-correlation, $\mathrm{r}_{\mathrm{s}}=-0.51, \mathrm{p}<0.05$ ). There was no correlation $\left(\mathrm{r}_{\mathrm{s}}=0.185, \mathrm{p}>0.05\right)$ between distance of displacement and the time taken to return to the capture site (Fig. 3), with fish displaced the shortest distance (e.g. Codes 155 and 84, $0.5 \mathrm{~km}$ ) taking nearly as many days to home as those displaced the longest distance (e.g. Code 116, $2.6 \mathrm{~km}$ ) (Table 1, Fig. 2).

Movements of most groupers at release sites tended to be haphazard and not directed, thereby yielding low linear ratios (Table 2). However, Code 37 exhibited a more directed movement ( $\mathrm{LR}=0.92$; Table 2, Fig. 2). Neither tidal state (spring vs neap tides) nor time of the day of observation (morning vs afternoon) had any effect on the magnitude of daily movements of the fish (2-way ANOVA: tide, $\mathrm{p}=0.608$; time, $\mathrm{p}=0.452$; tide $\times$ time, $\mathrm{p}=0.970)$.

Home-range size on return to capture locations ranged from 0.07 to $0.73 \mathrm{~km}^{2}$ (mean $0.344 \pm 0.23 \mathrm{~km}^{2}$, Fig. 2). Cumulative area occupied on return tended to reach an asymptote after approximately $1 \mathrm{wk}$ (Fig. 4). The shapes of the home ranges determined from the aspect ratios $(A R)$ varied from oblong $(A R>2)$ to circular $(\mathrm{AR}<2)$. Most fish were located at least every second day throughout the study, mostly near coral heads (Table 1). Fish that were not displaced (controls: Codes 96 and 160), remained near their capture sites throughout the experiment ( $\sim \mathrm{mo})$, although Code 160 suddenly disappeared from its home range after a long period (105 d) of residence. The home range of Code $160\left(0.389 \mathrm{~km}^{2}\right)$ was similar to the re-established ranges of displaced fish (Table 2), while Code 96 was consistently located on a single coral head.

Home range was significantly and negatively related to fish length $\left(\mathrm{r}^{2}=0.63, \mathrm{p}<0.05\right.$; Fig. 5). The smallest fish tagged ( 34 and $49 \mathrm{~cm}$ ) for which the home range could be estimated had much larger ranges than the larger individuals.

\section{DISCUSSION}

Of transplanted groupers, $67 \%$ homed back to their capture site, or $88 \%$ of transplanted fish whose fate was known. Most fish appeared to stay near the release site and to move short non-directional distances until some cue spurred them to return to their capture sites; once cued, they returned very quickly (most within $1 \mathrm{~d}$ of their last location at the release site). This notion is supported by the low values of linear ratios that suggest random movements around the release sites. The cue to return appears to be related to oceanographic conditions, in particular spring tides. Nearly all (88\%) homing groupers returned on spring tide (full-moon phase), and fish transplanted on spring tides returned more quickly. Spring tides in shallow reef lagoons (as at Malindi) are often characterized by fast-flowing and directional (parallel to the shore at Malindi) tidal currents (see Brakel 1982, Miller et al. 1985). It is therefore likely that these tidal currents could provide both a timing and a directional clue to homing groupers. Additionally, spring tides may transport olfactory cues indicative of a home reef much better than sluggish neap tides (Dodson 1988), permitting the groupers to home with greater success during this

Table 2. Epinephelus tauvina. Home range characteristics of individuals tracked within Malindi Marine Park, coastal Kenya. AR: aspect ratio (length/width) describing shape of home range; LR: linearity ratio at release site

\begin{tabular}{|c|c|c|c|}
\hline $\begin{array}{l}\text { Fish ID } \\
\text { code }\end{array}$ & $\begin{array}{l}\text { Home range } \\
\left(\mathrm{km}^{2}\right)\end{array}$ & AR & LR \\
\hline \multicolumn{4}{|c|}{ Experimental } \\
\hline 37 & 0.726 & 2.7 & 0.92 \\
\hline 36 & 0.394 & 2.3 & 0.21 \\
\hline 155 & 0.168 & 1.6 & 0.48 \\
\hline 116 & 0.212 & 1.4 & 0.05 \\
\hline 128 & 0.222 & 2.01 & 0.21 \\
\hline 84 & 0.241 & 1.5 & 0.37 \\
\hline 140 & 0.065 & 1.6 & 0.03 \\
\hline 152 & 0.274 & 1.3 & 0.05 \\
\hline \multicolumn{4}{|l|}{ Control } \\
\hline $96^{\mathrm{a}}$ & - & - & - \\
\hline 160 & 0.389 & 2.7 & 0.01 \\
\hline
\end{tabular}



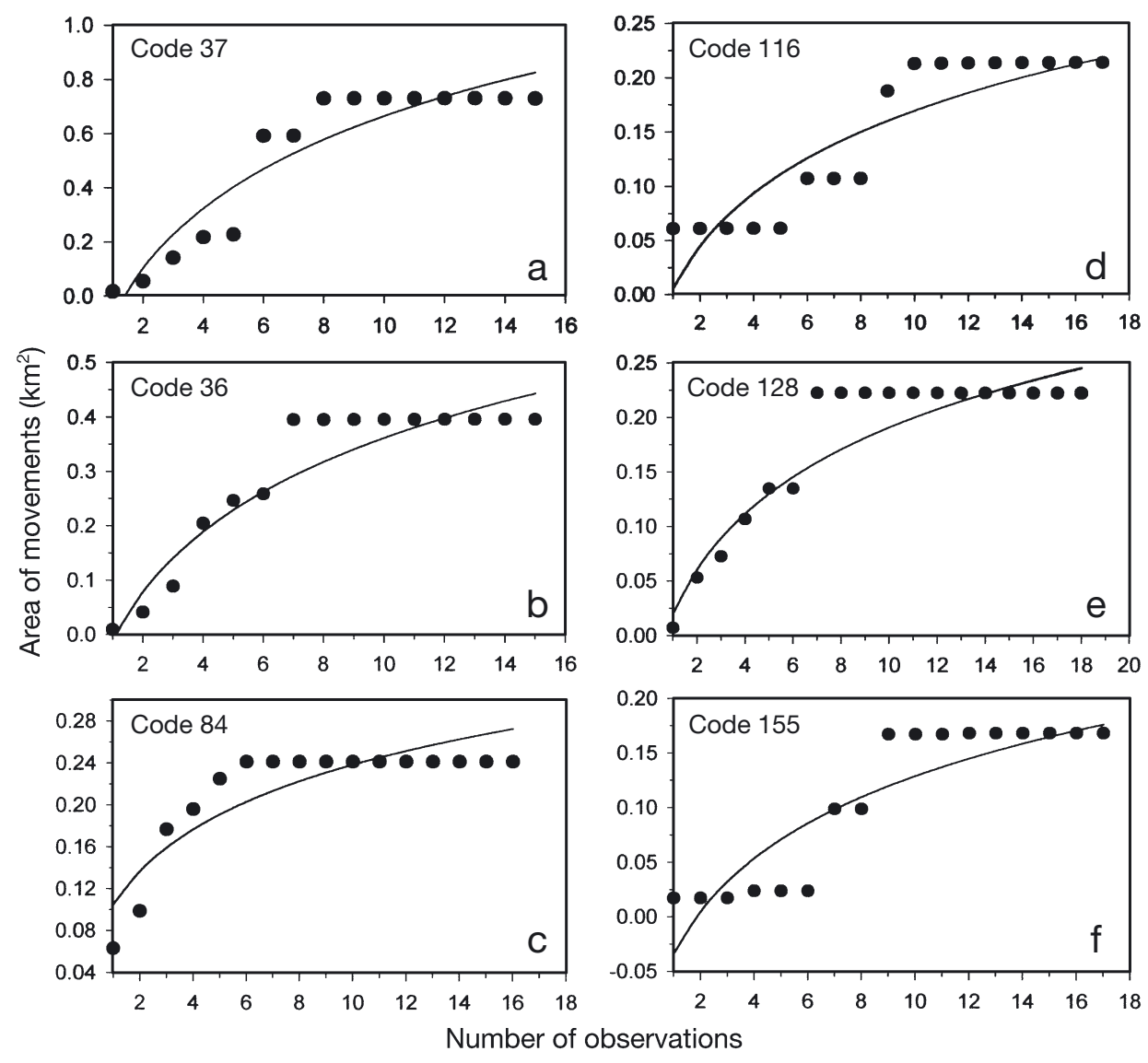

Fig. 4. Epinephelus tauvina. Cumulative area occupied upon return to capture sites following displacement within Malindi Marine Park, Kenya, reached asymptotes (approximated by the curves) within 1 wk of tracking

tidal phase. Elsewhere, Nasau groupers Epinephelus striatus are known to form spawning aggregations during full moon, and it is speculated that they use the lunar phase as a cue to migrate to spawning areas (Bolden 2000, Sala et al. 2001). Studies on spawning aggregations and grouper biology are lacking from

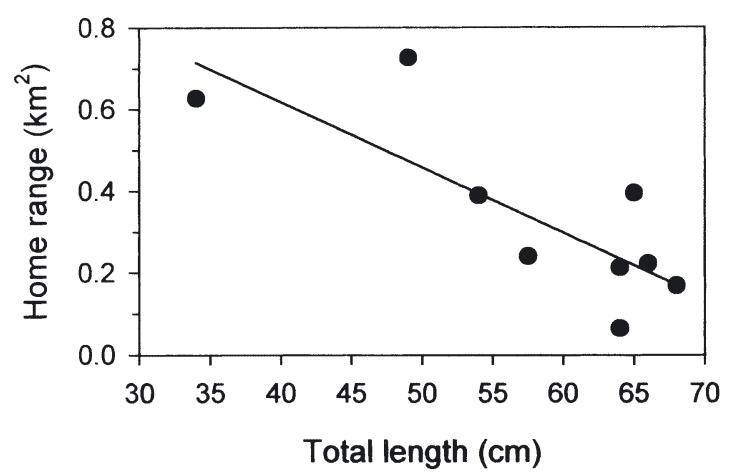

Fig. 5. Epinephelus tauvina. Relationship between home range size $\left(\mathrm{km}^{2}\right)$ and total length $(\mathrm{cm})$ of greasy groupers tracked within Malindi Marine Park, Kenya $\left(y=1.258-0.016 x_{t}\right.$

$$
\left.\mathrm{r}^{2}=0.63, \mathrm{p}<0.05\right)
$$

coastal Kenya. However, fishers often speak of historically high catches of groupers at certain reefs. If these catches were a result of spawning aggregations, then it is likely that the spring tide-homing relationship reported in this paper indicates the ability of groupers to use lunar phases to orient to and from reef sites.

Only the smallest transplanted fish (Code 152, $34 \mathrm{~cm}$ ) remained near the release site. It could be that the larger fish transplanted (most $>50 \mathrm{~cm}$ ) were more familiar with the park topography and hence returned to their capture sites more quickly. Spatial learning of home-reef topography is likely to be more developed in sedentary species (like groupers), so that natural selection may favor the development of homing mechanisms based on cognitive mapping, social transmission and landmark orientation (McCleave et al. 1984, Dodson 1988). The lack of a relationship between displacement distance and time required to return suggests that familiarity with the environment (spatial learning) is not the sole determinant of homing success. An alternative hypothesis for size-based homing success (and thought to be more likely) is ontogenetic establishment of a home range as fish mature (Lirman 
1994). Immature fish may not yet have become firmly attached to a home range. Code 152 was considerably smaller than the other tagged fish, perhaps the only juvenile tagged, and did not return to the capture site. It is likely that stable home ranges are established at a critical size when spatial learning becomes imprinted (Dodson 1988). However, the small sample size of small-sized groupers and the small displacement range was an obvious limitation in this study.

In Kenyan fisheries, commercial landings of groupers have declined steadily over the past 2 decades (Kenya Department of Fisheries unpubl. data). Worldwide, groupers have been overfished in many coastal areas (Russ 1991). The homing behavior and establishment of stable home ranges demonstrated in the present study indicates that marine protected areas have strong conservation potential for these fishes.

Acknowledgements. We are grateful to N. A. Muthiga for granting permission to work within the Park. We thank M. Ndegwa for field assistance, A. Simms for help with GPS data analysis, J. M. Green for valuable suggestions and R. Njue for logistic support. Funding was received from the International Foundation for Science (IFS, Sweden), the Fisheries Conservation Chair of Memorial University, Canada, and a Memorial-Canadian Development Agency fellowship to B.K.A.

\section{LITERATURE CITED}

Beets J, Friedlander A (1998) Evaluation of a conservation strategy: a spawning aggregation closure for red hind, Epinephelus guttatus, in the US Virgin Islands. Environ Biol Fish 55:91-98

Bolden SK (2000) Long-distance movement of a Nassau grouper (Epinephelus striatus) to a spawning aggregation in the Central Bahamas. Fish Bull Fish Wildl Serv US 98: 642-645

Brakel WH (1982) Tidal patterns on the east African coast and their implications for the littoral biota. In: Bryceson I (ed) Proc Symp Coastal and Marine Environments of the Red Sea, Gulf of Aden and Tropical Western Indian Ocean, Vol 2. ALESCO/UNESCO, Khartoum, p 403-418

Danielson BJ, Swihart KR (1987) Home range dynamics and activity patterns of Microtus ochrogaster and Synaptomys cooperi in syntopy. J Mammal 68:160-165

Dodson JJ (1988) The nature and role of learning in the orientation and migratory behaviour of fishes. Environ Biol Fish 23:161-182

Ditman AH, Quinn TP (1996) Homing in Pacific salmon: mechanisms and ecological basis. J Exp Biol 85:185-197

Gerking SD (1959) The restricted movements of fish populations. Biol Rev 34:221-242

Green JM (1971) High tide movements and homing behaviour in the tidepool sculpin, Oligocottus maculosus. J Fish Res Bd Can 28:383-389

Editorial responsibility: Charles Peterson (Contributing Editor), Morehead City, North Carolina, USA
Helfman GS, Meyer JL, McFarland WN (1982) The ontogeny of twilight migration patterns in the grunts (Pisces: Haemulidae). Anim Behav 32:379-384

Holland KN, Peterson JD, Lowe CG, Wetherbee BM (1993) Movements, distribution and the growth rates of the white goatfish Mulloides flavolineatus in a fisheries conservation zone. Bull Mar Sci 52:982-992

Lirman D (1994) Ontogenetic shifts in habitat preferences in three spot damselfishes Stegastes planifrons (Cuvier), in Roatan Island, Hondurans. J Exp Mar Biol Ecol 180:71-81

Marnane MJ (2000) Site-fidelity and homing behaviour in coral reef cardinal fishes. J Fish Biol 57:1590-1600

McCleave JD, Harden-Jones FR, Legget WC, Northcote TG (1984) Fish migration studies: future direction. In: McCleave JD, Arnold GP, Dodson JJ, Neil WH (eds) Mechanisms of migration in fishes. Plenum Press, New York, p 545-554

Miller JM, Crowder LB, Moser ML (1985) Migration and utilization of estuarine nurseries by juvenile fishes: an evolutionary perspective. Contrib Mar Sci 27:338-352

Morris AV, Roberts CM, Hawkins JP (2000) The threatened status of groupers (Epinephelinae). Biol Conserv 9: 919-942

Odum JC, Keunzler EJ (1955) Measurement of territory and home range size in birds. Auk 72:128-137

Papi F (ed) (1992) Animal homing. Chapman \& Hall, London

Quinn TP, Ditman AH (1992) Fishes. In: Papi F (ed) Animal homing. Chapman \& Hall, London, p 10-23

Robichaud D, Rose GA (2001) Multiyear homing of Atlantic cod to a spawning ground. Can J Fish Aquat Sci 58: 2325-2329

Rose GA (1993) Cod spawning on a migration highway in the north-west Atlantic. Nature 366:458-461

Russ GR (1991) Coral reef fisheries: effects and yield. In: Sale PF (ed) The ecology of fishes on coral reefs. Academic Press, San Diego, p 601-635

Sala E, Ballesteros E, Starr RM (2001) Rapid decline of Nassau grouper spawning aggregations in Belize: fishery management and conservation needs. Fisheries 26:23-30

Sale PF (1991) Introduction. In: Sale PF (ed) The ecology of fishes on coral reefs. Academic Press, San Diego, p 3-15

Sluka R, Chiappone M, Sullivan KM, Wright R (1997) The benefits of marine fishery reserve status for Nassau grouper Epinephelus striatus in the central Bahamas. Proc 8th Int Coral Reef Symp 2:86-127

Switzer PV (1993) Site-fidelity in predictable and unpredictable habitats. Evol Ecol 7:533-555

Warner RR (1995) Large mating aggregations and daily longdistance migrations in the bluehead wrasse, Thalassoma bifasciatum. Environ Biol Fish 44:337-345

Winter JD (1977) Summer home range movements and habitat use by four large mouth bass in Mary Lake, Minnesota. Trans Am Fish Soc 106:323-330

Winter JD, Ross JM (1982) Methods in analyzing fish habitat utilization from telemetry data. In: Armantrout N (ed) Proc Symp Acquisition and Utilization of Aquatic Habitat Inventory Information. American Fisheries Society, Portland, p 273-279

Zeller DC (1997) Home range and activity patterns of the coral trout Plectropomus leopardus (Serranidae) as determined by ultrasonic telemetry. Mar Ecol Prog Ser 162: 253-263

Submitted: February 20, 2003; Accepted: February 9, 2004 Proofs received from author(s): July 28, 2004 